\title{
Antimicrobial, antioxidant and cytotoxicity properties of selected wild edible fruits of traditional medicinal plants
}

\author{
Thilivhali Emmanuel Tshikalange ${ }^{\mathrm{a}}$, Darky Cheron Modishane ${ }^{\mathrm{a}}$, \\ and Frederick Tawi Tabit ${ }^{b}{ }^{*}$
}

a Department of Plant Science, Faculty of Natural and Agricultural Sciences, University of Pretoria, Hatfield, South Africa;

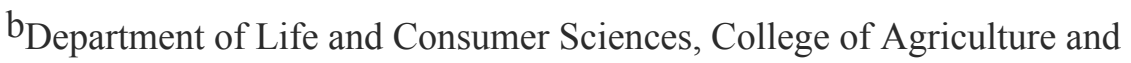
Environmental Sciences, University of South Africa, Florida, South Africa

*CONTACT Frederick Tawi Tabit tabitft@unisa.ac.za

Department of Life and Consumer Sciences, College of Agriculture and Environmental Sciences, University of South Africa, Cnr Christiaan de Wet Road and Pioneer Avenue, Florida 1710, South Africa. 


\begin{abstract}
The fruit pulp extracts of 12 selected ethnobotanical wild edible fruits were investigated for their antimicrobial, antioxidant and cytotoxicity properties. Methanol extracts of the pulps were prepared and tested against five micro-organisms (Salmonella typhi, Streptococcus pyogenes, Bacillus cereus, Klebsiella pneumoniae and Prevotella intermedia). The fruit pulp extracts of the wild edible plants exhibited different degrees of antimicrobial activity, with Adansonia digitata exhibiting a considerable level antimicrobial activity against Salmonella typhi. The fruit pulp extracts of $A$. digitata exhibited the best antioxidant activity. None of the fruit pulp extracts were toxic to humans. The results show the possibility of using these fruit pulps for the development of functional foods with medicinal benefits.
\end{abstract}

KEY WORDS: Pulp extracts, wild fruits, methanolic extracts, minimum inhibitory concentration, cytotoxicity

\title{
INTRODUCTION
}

Wild edible plants play an important role in human lives considering that, among their many uses, they are often used as food and medicine and for shelter (14). A wild edible plant is defined as an indigenous plant with one or more parts that can be used as food if gathered at an appropriate stage of growth and properly prepared (23). Wild edible fruits are consumed by many people in rural communities in many developing nations, as they cannot afford commercialised fruit and vegetables. Wild edible fruits are vital sources of essential nutrients, including vitamins and minerals, that are necessary for the proper functioning of the body (25).

Many of these wild edibile plants and fruits have been found to possess high in-vitro antimicrobial activity, hence they are a promising source of antimicrobial ingredients for the food industry (22). In recent years, many traditional edible plant species have been studied for their 
potential biological and health benefits, including their antioxidant, anticancer, anti-aging, antiatherosclerotic, antimicrobial and anti-inflammatory activities $(28,31,32)$.

Many wild fruits contain polyphenols which are known for their anti-oxidant activities hence their role in the prevention of various diseases associated with oxidative stress, such as cancer, cardiovascular disorders and neurodegenerative diseases (2).

The antioxidants present in wild fruits have been associated with beneficial health effects, such as protecting biomolecules from oxidative damage by scavenging free radicals and inactivating other pro-oxidants (16).

Evidence from previous studies indicates that phenolic phytochemicals found in wild fruits can exhibit antimicrobial activity against some foodborne pathogens responsible for foodborne disease outbreaks $(18,21)$. Thus, it is of great importance to screen wild edible fruit pulp of traditional medicinal plants for their medicinal properties the possibility to be used for the production of functional foods. The objective of this study was therefore to investigate the antioxidant, antimicrobial and cytotoxicity properties of the wild edible fruits of 12 selected ethnobotanical medicinal plants.

\section{MATERIALS AND METHODS}

Collection of plant materials and preparation of fruit pulp extracts

Mature edible wild fruits of 12 traditional medicinal plants: A. digitata, Berchemia discolor, Manilkara mochisia, Ximenia caffra, Strychnos madagascariensis, Strychnos pungens, Strychnos spinosa, Landolphia kirkii, Boscia albitrunca, Xanthocercis zambesiaca, Englerophytum megalismontanum magalismontanum and Garcinia livingstonei (Table 1) were collected from the Mutale Local Municipality, which is located in the north-eastern part of the Limpopo Province of South Africa. The selection and collection of a particular fruit was based on consumption and usage information obtained from discussions with rural community members. From each plant, two 
Table 1. Minimum inhibitory concentrations (MIC) and maximum bactericidal concentrations (MBC) of extracts of selected traditional plants on selected foodborne bacteria

\begin{tabular}{|c|c|c|c|c|c|c|c|c|c|c|}
\hline \multirow[t]{2}{*}{ Plant extracts } & \multicolumn{2}{|c|}{ MIC (mg/ml) } & \multicolumn{8}{|c|}{$\mathrm{MBC}(\mathrm{mg} / \mathrm{ml})$} \\
\hline & S.t & S.p & B.c & K.p & P.i & S.t & S.p & B.c & K.p & P.i \\
\hline Adansonia digitata & 6.3 & 6.3 & 1.6 & 12.5 & $>25.0$ & 6.3 & 25.0 & 6.3 & 25.0 & $>25.0$ \\
\hline Berchemia discolor & 6.3 & 6.3 & 3.1 & 6.3 & $>25.0$ & 12.5 & $>25.0$ & 12.5 & $>25.0$ & $>25.0$ \\
\hline Manilkara mochisia & 12.5 & 12.5 & 1.6 & 0.4 & 25.0 & 12.5 & $>25.0$ & 3.1 & 3.1 & $>25.0$ \\
\hline Ximenia caffra & 12.5 & 12.5 & 6.3 & 25.0 & 25.0 & $>25.0$ & $>25.0$ & 12.5 & $>25.0$ & $>25.0$ \\
\hline $\begin{array}{l}\text { Strychnos } \\
\text { madagacariensis }\end{array}$ & 12.5 & 12.5 & 6.3 & $>25.0$ & $>25.0$ & $>25.0$ & $>25.0$ & 12.5 & $>25.0$ & $>25.0$ \\
\hline Strychnos pungens & 12.5 & 12.5 & $>25.0$ & 25.0 & $>25.0$ & 25.0 & $>25.0$ & $>25.0$ & $>25.0$ & $>25.0$ \\
\hline Strychnos spinosa & 25.0 & $>25.0$ & 1.6 & 12.5 & $>25.0$ & $>25.0$ & $>25.0$ & 6.1 & $>25.0$ & $>25.0$ \\
\hline Landolphia kirkii & 25.0 & 25.0 & 6.3 & 6.3 & $>25.0$ & $>25.0$ & $>25.0$ & 25.0 & $>25.0$ & $>25.0$ \\
\hline Boscia albitrunca & 6.3 & 6.3 & $>25.0$ & 12.5 & $>25.0$ & 12.5 & $>25.0$ & $>25.0$ & $>25.0$ & $>25.0$ \\
\hline $\begin{array}{l}\text { Xanthocercis } \\
\text { zambesiaca }\end{array}$ & 12.5 & $>25.0$ & 6.3 & 6.3 & $>25.0$ & $>25.0$ & $>25.0$ & 25.0 & $>25.0$ & $>25.0$ \\
\hline $\begin{array}{l}\text { Englerophytum } \\
\text { megalismontanum }\end{array}$ & 12.5 & 6.3 & 12.5 & 12.5 & $>25.0$ & $>25.0$ & $>25.0$ & 25.0 & $>25.0$ & $>25.0$ \\
\hline Garcinia livingstonei & 25.0 & 12.5 & 3.1 & 6.3 & $>25.0$ & 12.5 & $>25.0$ & 25.0 & 25.0 & $>25.0$ \\
\hline
\end{tabular}

NB: S.t, Salmonella typhimurium ATCC 14028; S.p, Streptococcus pyogenes ATCC 21059; B.c, Bacillus cereus MTCC 430; K.p, Klebsiella pneumoniae ATCC 13883; P.i, Privotella intermedia ATCC 25611 
mature fruits which were ready for consumption were harvested during the fruiting periods of each plant. These fruits were transported on ice block immediately after harvest to the laboratory for further processing within 12 hours. Voucher specimens of each fruit were prepared and deposited at the HGWJ Schweitkerdt Herbarium of the University of Pretoria in South Africa. The fruit pulps were air dried and ground into a fine powder, after which $20 \mathrm{~g}$ of each powdered material was homogenised in $70 \%$ methanol and left on a shaker for five days to obtain fruit pulp solutions. The fruit pulp solutions were filtered (using Whatman filter paper No. 1 [110mm diameter] - Merck Chemicals [Pty] Ltd, Wadeville, South Africa) and concentrated (using the Büchi Rotavapor R200 - Labotec [Pty] Ltd, Halfway House, South Africa) to obtain fruit pulp extracts. The extracts were freeze dried, using a Virtis Bench Top Manifold Freeze Dryer (Sp Scientific [Pty] Ltd, New York, United States of America).

Preparation of test micro-organisms

The micro-organisms used in this study were Salmonella typhimurium (ATCC 14028), Streptococcus pyogenes (ATCC 21059), Bacillus cereus (MTCC 430) and Klebsiella pneumoniae (ATCC 13883) which were grown at $37^{\circ} \mathrm{C}$ for $24 \mathrm{~h}$ in nutrient broth and Privotella intermedia (ATCC 25611) which was grown at $37^{\circ} \mathrm{C}$ for $24 \mathrm{~h}$ in Casein-peptone Soy Agar medium (CASO) (Merck SA [Pty] Ltd) under anaerobic conditions in a jar with anaerocult A (Merck SA [Pty] Ltd). The subculturing of microbial cultures was done once weekly.

Broth microdilution assays

The microdilution technique, using 96-well microplates (9), was used to obtain the minimum inhibitory concentration (MIC) and minimum bactericidal concentration (MBC) values of the crude extracts of the fruit pulps against the selected micro-organisms. The extracts were serially diluted in the 96-well plate with 48-hour-old micro-organisms culture which had been serially diluted to $5 \mathrm{x}$

$10^{6} \mathrm{CFU} / \mathrm{ml}$ following incubation at $37^{\circ} \mathrm{C}$. The final concentration of extracts and positive controls (CHX) ranged from $25.0 \mathrm{mg} / \mathrm{ml}$ to $0.8 \mathrm{mg} / \mathrm{ml}$. Microbial growth was indicated by adding 
$40 \mu \mathrm{l}(0.2 \mathrm{mg} / \mathrm{ml}) p$-iodonitrotetrazolium violet (INT) (Sigma-Aldrich, South Africa) to micro-plate wells and incubated at $37^{\circ} \mathrm{C}$ for $48 \mathrm{~h}$. MIC values were determined as the lowest concentration of plant extracts that inhibited the growth of micro-organism and for which there was no change in the colour change of INT. The MBC of the pulp extracts were determined by adding $50 \mu 1$ of the suspensions from the wells, which did not show any growth after incubation during MIC assays, to $150 \mu \mathrm{l}$ fresh broth. These suspensions were re-incubated at $37^{\circ} \mathrm{C}$ for $48 \mathrm{~h}$ and $40 \mu 1(0.2 \mathrm{mg} / \mathrm{ml}) \mathrm{INT}$

added. The MBC values were determined as the lowest concentration of plant extract that inhibited $100 \%$ growth of micro-organisms and for which there was no change in the colour change of INT

\section{Antioxidant assay}

The free radical scavenging activities were measured using 1,1 diphenyl-2-picryl-hydraxyl (DPPH) assay $(8,12)$ with slight modifications. The extracts and vitamin $\mathrm{C}$ (positive control), $1000 \mu \mathrm{g} / \mathrm{ml}$ $(20 \mu 1)$, were added in the first three wells of a 96-well plate containing $200 \mu$ l distilled water to make up a final concentration of $100 \mu \mathrm{g} / \mathrm{ml}$. The remaining wells were filled with $110 \mu \mathrm{l}$ distilled water. The $100 \mu \mathrm{g} / \mathrm{ml}$ extracts and vitamin $\mathrm{C}$ in the first rows were serially diluted by adding $20 \mu \mathrm{l}$ to the wells (which had been dispensed with $110 \mu$ distilled water), followed by $90 \mu \mathrm{DPPH}$ $(90 \mathrm{mM})$ methanolic solution to obtain final concentrations of the extracts (which ranged from 100 to $0.8 \mu \mathrm{g} / \mathrm{ml}$ ). The plates were incubated at $37^{\circ} \mathrm{C}$ for 30 minutes and the absorbance was measured at $517 \mathrm{~nm}$, using the enzyme-linked immunosorbent assay (ELISA) plate reader. The percentage radical scavenging activity in the extracts was determined through comparison with ethanol (blank). The inhibition ratio was calculated as follows: \% DPPH radical scavenging $=(\mathrm{AC}-\mathrm{AS}) / \mathrm{AC} \times 100$, where $\mathrm{AC}$ is the absorbance of the control solution (containing only DPPH solution) and AS is the absorbance of the sample in the DPPH solution. The percentage of DPPH radical scavenging was plotted against the plant extract/compound concentrations $(\mu \mathrm{g} / \mathrm{ml})$ to determine the concentration of extract/compound required to scavenge $\mathrm{DPPH}$ by $50 \%\left(\mathrm{EC}_{50}\right)$. 
Cytotoxicity assay

Only the cytoxicity of six selected fruits of traditional medicinal plants that exhibited considerable antimicrobial activities and which were mostly utilised locally in the Limpopo Province was analysed (A. digitate, B. discolour, L. kirkii, M. mochisia, X. zambesiaca and G. livingstonei). The cytotoxocity of the active methanol extracts was measured against human kidney cells (HEK 293) by means of the XTT (sodium 3'-[1-(phenyl amino-carbonyl)-3,4-tetrazolium]-bis-[4-methoxy-6nitro] benzene sulphonic acid hydrate) method (36). In a microtiter plate, the outer wells were filled with $200 \mu 1$ of incomplete medium (without FBS or PS) and the inner wells were filled with $100 \mu 1$ cell suspension and incubated for $24 \mathrm{~h}$ in a humidified atmosphere, with $5 \% \mathrm{CO}_{2}$ at $37^{\circ} \mathrm{C}$. The plant extracts were serially diluted, making up various concentrations with a range of 400 to $3.1 \mu \mathrm{g} / \mathrm{ml}$ added to the microtiter plate containing human kidney cells, and incubated for 72 hours. Each extract was tested in triplicate. Medium control and DMSO control were included in triplicate for each sample that was tested. XTT reagent was prepared to make a final concentration of $0.3 \mathrm{mg} / \mathrm{ml}$, which was added to the cells in the microtiter plate and incubated for two to three hours. Included in the assay was positive drug control actinomycon-D (at various concentrations, ranging from 0.05 to $0.0003 \mu \mathrm{g} / \mathrm{ml}$ ). After incubation, the absorbance of the colour was spectrophotometrically quantified using an ELISA plate reader, which measured the optical density at $490 \mathrm{~nm}$ with a reference wavelength of $690 \mathrm{~nm}$.

Statistical analysis

The statistical analysis was conveyed as means \pm SD using GraphPad Prism 4.0 with a significant difference of $(P<0.05)$.

\section{RESULTS}

Inhibition activities of plant extracts 
The fruit pulp extracts of $A$. digitata, B. discolor and $B$. albitrunca showed the highest antimicrobial activities against Salmonella typhi, with each having a MIC value of $6.3 \mathrm{ug} / \mathrm{ml}$. This was followed by M. mochisia, X. caffra, S. madagacariensis, S. pungens, X. zambesiaca and E. megalismontanum (with each having a MIC value of $12.5 \mathrm{mg} / \mathrm{ml}$ ) and L. kirkii and G. livingstonei (with each having a MIC value of $25 \mathrm{mg} / \mathrm{ml}$ ). The fruit pulp extracts of $A$. digitata, B. discolor, $B$. albitrunca and E. megalismontanum showed the highest inhibition activities against Streptococcus pyogenes, with each having a MIC value of $6.3 \mathrm{mg} / \mathrm{ml}$. This was followed by M. mochisia, X. caffra, S. madagacariensis, S. pungens and G. livingstonei (with each having a MIC value of $12.5 \mathrm{mg} / \mathrm{ml}$ ) and $S$. spinose, L. kirkii and X. zambesiaca (with each having MIC values $\geq$ $25.0 \mathrm{mg} / \mathrm{ml})($ Table 1$)$.

Bacillus cereus was most susceptible to the different plant extracts in which the fruit pulp extracts of $A$. digitata, M. mochisia and $S$. spinose showed the highest inhibition activities against Bacillus cereus, with each having a MIC value of $1.6 \mathrm{mg} / \mathrm{ml}$. This was followed by the fruit pulp extracts of $B$. discolor and G. livingstonei, with each having a MIC value of $3.1 \mathrm{mg} / \mathrm{ml} ; X$. caffra, S. madagacariensis, L. kirkii and X. zambesiaca, with each having a MIC value of $6.3 \mathrm{mg} / \mathrm{ml} ; E$. megalismontanum, with a MIC value of $12.5 \mathrm{mg} / \mathrm{ml}$; and S. pungens and B. albitrunca, with each having MIC values $\geq 25.0 \mathrm{mg} / \mathrm{ml}$ (Table 1 ).

The fruit pulp extracts of M. mochisia showed the highest inhibition activities against Klebsiella pneumoniae, with a MIC value of $0.4 \mathrm{mg} / \mathrm{ml}$. This was followed by the fruit pulp extracts of B. discolor, L. kirkii, X. zambesiaca and G. livingstonei, with each having a MIC value of $6.3 \mathrm{mg} / \mathrm{ml} ;$ A. digitata, S. spinose, B. albitrunca and E. megalismontanum, with each having a MIC value of $12.5 \mathrm{mg} / \mathrm{ml}$; and X. caffra, S. madagacariensis and S. pungens, with each having MIC values $\geq 25.0 \mathrm{mg} / \mathrm{ml}$. Privotella intermedia was the least inhibited of all the micro-organisms tested, with MIC values $\geq 25 \mathrm{mg} / \mathrm{ml}$ for all the plant extracts (Table 1).

Bactericidal activities of plant extracts 
Most of the plant extracts showed very little bactericidal activities against the tested bacteria, at $\mathrm{MBC}$ values $\geq 25.0 \mathrm{mg} / \mathrm{ml}$, with no plant extract having a $\mathrm{MBC}$ value of less than $25 \mathrm{mg} / \mathrm{ml}$ against Streptococcus pyogenes and Privotella intermedia. Bacillus cereus was most susceptible to six of the 12 extracts analysed (at MBC values of $\leq 12.5 \mathrm{mg} / \mathrm{ml}$ ), compared to five of the 12 extracts for Streptococcus pyogenes and one of the 12 extracts for Klebsiella pneumoniae. M. mochisia showed the most bactericidal activity, with MBC values of $3.1 \mathrm{mg} / \mathrm{ml}$ against Bacillus cereus and Klebsiella pneumoniae and MBC values of $12.5 \mathrm{mg} / \mathrm{ml}$ against Salmonella typhi. This was followed by $A$. digitata with $\mathrm{MBC}$ values of $6.3 \mathrm{mg} / \mathrm{ml}$ against Streptococcus pyogenes and Bacillus cereus. A. digitate and B. discolor also showed some bactericidal activities against Streptococcus pyogenes and Bacillus cereus, with MBC values of $12.5 \mathrm{mg} / \mathrm{ml}$.

Antioxidant and cytotoxicity activities of plant extracts

Of the 12 extracts tested, only the methanol extract of $A$. digitata showed significant antioxidant activity, with an $\mathrm{IC}_{50}$ value of $16.18 \mathrm{ug} / \mathrm{ml}$ - up to 10 times larger than that of vitamin $\mathrm{C}$ $(10.67 \mathrm{ug} / \mathrm{ml})$; all the other extracts had IC50 values above $100 \mathrm{ug} / \mathrm{ml}$ (Table 2). The fruits of the six selected fruits of traditional medicinal plants that exhibited considerable antimicrobial activities were found to be non-toxic to human kidney cells, considering that the $\mathrm{IC}_{50}$ of all the plant extracts were above $400 \mu \mathrm{g} / \mathrm{ml}$ (Figure 1).

\section{DISCUSSION}

Antimicrobial activities of plant extracts

The root, fruit and leave extracts of many medicinal plants have been found to possess significant antimicrobial activity against many micro-organisms, including foodborne pathogens such as Salmonella typhi, Streptococcus pyogenes, Bacillus cereus and Escherichia coli (15). In this study, the fruit pulp extracts of $A$. digitata, B. discolor and B. albitrunca showed the highest antimicrobial activities against Salmonella typhi, Streptococcus pyogenes and Bacillus cereus. Surprisingly, the 
Table 2. The free radical activity of extracts of selected traditional plants

\begin{tabular}{|l|l|l|}
\hline Plant extract & $\begin{array}{l}\mathbf{I C}_{\mathbf{5 0}} \\
(\boldsymbol{\mu g} / \mathbf{m l})\end{array}$ & STD \\
\hline Vitamin C & 1.67 & \pm 1.95 \\
\hline Adansonia digitata & 16.18 & \pm 2.14 \\
\hline Berchemia discolor & $>100$ & \pm 1.85 \\
\hline Manilkara mochisia & $>100$ & \pm 1.82 \\
\hline Ximenia caffra & $>100$ & \pm 2.1 \\
\hline $\begin{array}{l}\text { Strychnos } \\
\text { madagacariensis }\end{array}$ & $>100$ & \pm 2.85 \\
\hline Strychnos pungens & $>100$ & \pm 1.82 \\
\hline Strychnos spinosa & $>100$ & \pm 3.1 \\
\hline Landolphia kirkii & $>100$ & \pm 2.22 \\
\hline Boscia albitrunca & $>100$ & \pm 2.1 \\
\hline $\begin{array}{l}\text { Xanthocercis } \\
\text { zambesiaca }\end{array}$ & $>100$ & \pm 1.85 \\
\hline $\begin{array}{l}\text { Englerophytum } \\
\text { megalismontanum }\end{array}$ & $>100$ & \pm 3.52 \\
\hline Garcinia livingstonei & $>100$ & \pm 1.1 \\
\hline
\end{tabular}




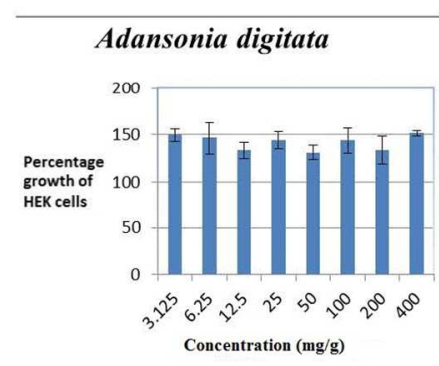

a

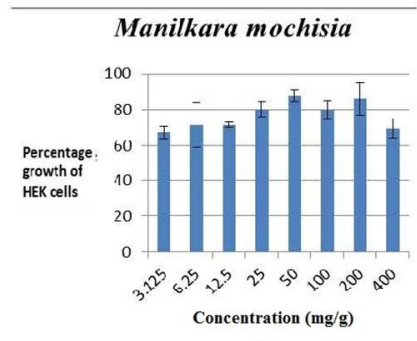

d

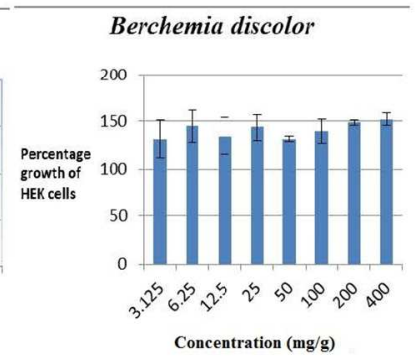

b

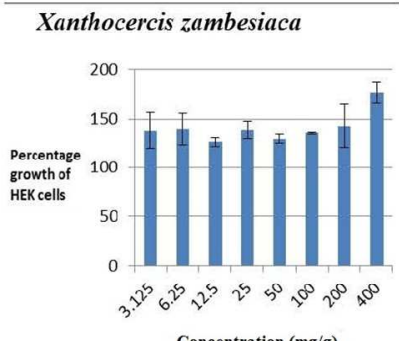

e

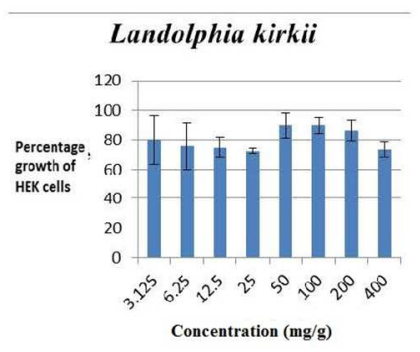

c

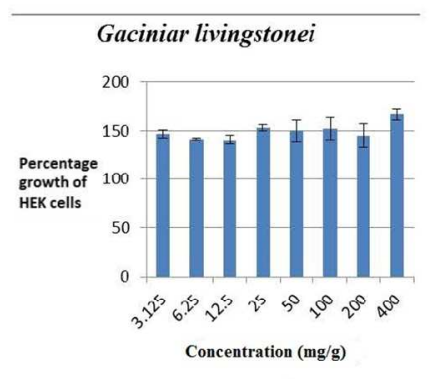

f

Figure 1. The cytotoxicity effects of the six selected active extracts (Adonsonia digitata, Berchemia discolor, Manilkara mochisia, Xanthocercis zambesiaca and Garcinia livingstonei) on the growth of human kidney cells (HEK293)

$254 \times 190 m m(145 \times 149$ DPI $)$ 
fruit pulp extracts $A$. digitata presented good antimicrobial activity against Salmonella typhi and Streptococcus pyogenes, considering that various extracts of $A$. digitata have previously been found not to present significant antibacterial activity against a vast array of tested bacteria strains $(19,29)$.

However, extracts of $B$. discolor are reputable for their antimicrobial activities against different strains of bacteria, including strains of drug resistant Mycobacterium tuberculosis isolates (11). Various extracts of $B$. albitrunca have been found to possess significant antimicrobial activities against some bacteria, including B. subtilis and K. pneumonia (27).

The fruit pulp extracts of E. megalismontanum exhibited good antibacterial activity against Streptococcus pyogenes, despite previous findings where various extracts were found to show moderate antimicrobial activity against selected micro-organism. Furthermore, Gram-negative bacteria were more resistant to the extracts in comparison to Gram-positive bacteria (24). X. caffra (which showed moderate antimicrobial activity in this study) was found to have considerable invitro activity against Candida species (10), while the extracts Strychnos pungens and X. zambesiaca have been found to exhibit good to moderated antimicrobial activities against bacteria and fungi $(13,30)$.

The fact that Bacillus cereus was most susceptible to the different plant extracts confirms the finding of another study where Gram-positive bacteria, such as B. cereus, were found to be more susceptible to other medicinal plant extracts than other bacteria (26). Surprisingly, the fruit pulp extracts of Manilkara mochisia showed very good antimicrobial activities against Klebsiella pneumoniae, considering that very little information is available in the literature about the antimicrobial activities of the extract of this plant. The fact that Privotella intermedia showed the least antimicrobial activity came as surprise, as it was previously found to possess moderate antimicrobial activity (20).

Based on the MBC results of the plant extracts, it is clear that the antibacterial activity exhibited by the extracts are mostly bacteriostatic, considering that only extracts of M. mochisia, A. 
digitata and B. discolor exhibited significant bactericidal activity. Extracts of medicinal plants often exhibit better bacteriostatic properties than bactericidal properties for the same micro-organisms (33;35). The antimicrobial activity of the M. mochisia extract against Salmonella typhi is one of the best that have so far been registered for traditional medicinal plant extracts, considering that most authors found moderate MBC activities (1).

Antioxidant and cytotoxicity activities of plant extracts

The fact that all the fruit extracts exhibited antioxidant activity is not surprising, since different fruit parts have often been found to exhibit antioxidant activities (17). The fact that the fruit pulp extract of $A$. digitata showed significant antioxidant activity does not come as surprise, as another author also found that it exhibited high antioxidant activity compared to other fruits (34). The finding that none of the fruit pulp extracts were toxic to human kidney cells is in line with previous studies where medicinal plants were proven to be non-toxic to humans at the levels in which they are naturally consumed (3,5). It should be noted that in sub-Saharan Africa the fruits of many of the plant used in this study are often used traditional as food while the leaves, backs, roots and seeds extract are often used for medicinal purposes (6).

\section{CONCLUSION}

The pulp extracts of the wild edible fruits from traditional medicinal plants exhibited different degrees of antimicrobial activities, with $A$. digitata exhibiting a substantial antimicrobial activity against Salmonella typhi a Gram-negative bacteria. Only the pulp extracts of $A$. digitata and $B$.

discolor exhibited substantial bactericidal activity against B. cereus, while that of M. mochisia exhibited substantial bactericidal activity against $K$. pneumoniae. When compared to the other pulp extracts, the extract of $A$. digitata exhibited the best antioxidant activity. These results show that these fruit pulp extracts possess some bioactive properties that can be exploited for medical purposes. 


\section{REFERENCES}

1. Akinyemi, K.O., U.E. Mendie, S.T. Smith, A.O. Oyefolu, and A.O. Coker. 2005. Screening of some medicinal plants used in South-West Nigerian traditional medicine for antiSalmonella typhi activity. J. Herb. Med. 5(1):45-60.

2. Atawodi, S.E., J.C. Atawodi, P. Idakwo, B. Pfundstein, R. Haubner, G. Wurtele, B. Spiegelhalder, H. Bartsch, and R.W. Owen. 2009. Evaluation of the polyphenol composition and antioxidant activity of African variety of Dacryodes edulis (G.Don) H.J Lam Fruit. J. Med. Food 12 (6):1321-1325.

3. Awah, F.M., P.N. Uzoegwu, P. Ifeonu, J.O. Oyugi, J. Rutherford, X. Yao, and M.O. Eze. 2012. Free radical scavenging activity, phenolic contents and cytotoxicity of selected Nigerian medicinal plants. Food Chem. 131(4):1279-1286.

4. Bharucha, Z., and J. Pretty. 2010. The roles and values of wild foods in agricultural systems. Philos. Trans. R. Soc. Lond B Biol. Sci. 365(1554):2913-2926.

5. Cercato, L.M., P.A.S. White, F.K. Nampo, M.R.V. Santos, and E.A. Carmago. 2015. A systematic review of medicinal plants used for weight loss in Brazil: Is there potential for obesity treatment? J. Ethnopharmacol. 176, 286-296.

6. Civandi, E., N. Mukonowenzou, T. Nyakudya, K.H. Erlwanger. 2015. Potential of indigenous fruit-bearing trees to curb malnutrition, improve household food security, income and community health in Sub-Saharan Africa: A review. Food Res. Int. 76(4), 980985.

7. Cohen, M.A., M.D. Husband, S.L. Yoder, J.W. Gage, and G.E. Roland, 1998. Bacterial eradication by clinafloxacin, CI-990, and ciprofloxacin employing MBC test, in-vitro timekill and in-vivo time-kill studies. J. Antimicrob. Chemother. 41(6):605-614.

8. Du Toit, R., Y. Vosteedt, and Z. Apostolide. 2001. Comparison of the antioxidant content of fruits, vegetables and tea measured as vitamin equivalents. Toxicology 166(1-2):63-69. 
9. Eloff, J.N., 1998. A sensitive and quick microplate method to determine the minimal inhibitory concentration of plant extracts for bacteria. Planta Med. 64(8):711-713.

10. Fabry, W., P. Okemo, R. Ansorg. 1996. Fungistatic and fungicidal activity of east African medicinal plants. Mycoses 39, 67-70.

11. Green, E., A. Samie, C.L. Obi, P.O. Bessong, and R.N. Ndip. 2010. Inhibitory properties of selected South African medicinal plants against Mycobacterium tuberculosis. J. Ethnopharmacol. 130(1):151-157.

12. Gurava, S.S., N.S. Deshkar, S.K. Tilloo, N.J. Duragkar, and K. Burade. 2013. Antimicrobial and Antioxidant Evaluation of Flacourtia Ramontchi L. Herit. J. Herbs Spices Med. Plants 19(1):76-95.

13. Isa, A.I., M.D. Awouafack, J.P. Dzoyem, M. Aliyu, R.A. Magaji, J.O. Ayo, and J.N. Eloff. 2014. Some Strychnos spinosa (Loganiaceae) leaf extracts and fractions have good antimicrobial activities and low cytotoxicities. BMC Complement Altern. Med. 14, 456.

14. Kala, C.P., 2015. Medicinal and aromatic plants: Boon for enterprise development. J. Appl. Res. Med. Aromat. Plants 2(4):134-139.

15. Kang, C-G., D-S. Hah, C-H. Kim, Y-H. Kim, E. Kim, and J-S. Kim. 2011. Evaluation of antimicrobial activity of the methanol extracts from 8 traditional medicinal plants. Toxicol. Res. 27:31-36.

16. Kappel, V.D., G.M. Costa, G. Scola, F.A. Silva, M.F. Landell, P. Valente, D.G. Souza, D.C. Vanz, F.H. Reginatto, J.C.F. Moreira. 2008. Phenolic content and antioxidant and antimicrobial properties of fruits of Capsicum baccatum L. var. pendulum at different maturity stages. J. Med. food 11 (2):267-274.

17. Kubola, J., S. Siriamornpun. 2011. Phytochemicals and antioxidant activity of different fruit fractions (peel, pulp, aril and seed) of Thai gac (Momordica cochinchinensis Spreng). Food Chem. 127(3):1138-1145. 
18. Kyu, H.K., W. You-Ho, S.K. Dong, J.P. Hun, and S.K.Youn. 2007. Antimicrobial activity of an edible wild plant, Apiifolia virgins bower (Clematis apiifolia DC). Food Sci. Biotechnol. 16, 1051-1054.

19. Lagnika, L., M. Amoussa, Y. Adjovi, and A. Sanni. 2012. Antifungal, antibacterial and antioxidant properties of Adansonia digitata and Vitex doniana from Bénin pharmacopeia. J. Pharmacogn. Phytochem. 4(4):44-52.

20. Larsen, T., N-E. Fiehn, and E. Østergaard. 1996. The susceptibility of dental plaque bacteria to the herbs included in Longo Vital ${ }^{\circledR}$. Microb. Ecol. Health Dis. 9:91-95.

21. Lin, Y.T., Y.I. Kwon, R.G. Labbe, K. Shetty. 2005. Inhibition of Helocobacter pylori and associated urease by oregano and cranberry phytochemical synergies. Appl. Environ. Microbiol. 71:8558-8564.

22. Liu, X., M. Zhao, W. Luo, B. Yang, Y. Jiang. 2009. Identification of volatile components in Phyllanthus emblica L. and their antimicrobial activity. J. Med. Food 12 (2):423-428.

23. Mahapatra, A.K., S. Mishra, U.C. Basak, and P.C. Panda. 2012. Nutritional analysis of some selected wild edible fruits of deciduous forests of India: an explorative study towards nonconventional bio-nutrition. Adv. J. Food Sci. Technol. 4:15-21.

24. More, G., T.E. Tshikalange, N. Lall, F. Botha, J.J.M. Meyer. 2008. Antimicrobial activity of medicinal plants against oral microorganisms. J Ethnopharmacol. 119(3):473-477.

25. Motlhanka, D.M., and S.W. Makhabu. 2011. Medicinal and edible wild fruit plants of Botswana as emerging new crop opportunities. J. Med. Plants Res. 5(10):1836-1842. 2011.

26. Parekh, J., and S. Chanda. 2007. Antibacterial and phytochemical studies on twelve species of Indian medicinal plants. Afr. J. Biomed. Res. 10:175-181.

27. Pendota, S.C., M.A. Aderogba, and J. Van Staden. 2015. In-vitro antimicrobial activity of extracts and an isolated compound from Boscia albitrunca leaves. S. Afr. J. Bot. 96:91-93. 
28. Pirbalouti, A.G., A. Siahpoosh, M. Setayesh, and L. Craker. 2014. Antioxidant activity, total phenolic and flavonoid contents of some medicinal and aromatic plants used as herbal teas and condiments in Iran. J. Med. Food 17(10): 1151-1157.

29. Seukep, J.A., A.G. Fankam, D.E. Djeussi, I.K. Voukeng, S.B. Tankeo, J.A.K. Noumdem, A.H.L.N. Kuete, and V. Kuete. 2013. Antibacterial activities of the methanol extracts of seven Cameroonian dietary plants against bacteria expressing MDR phenotypes. Springerplus 2: 363 .

30. Shai, L.J., M.A. Chauke, S.R. Magano, A.M. Mogale, and J.N. Eloff. 2013. Antibacterial activity of sixteen plant species from Phalaborwa, Limpopo Province, South Africa. J. Med. Plant Res. 7(26):1899-1906.

31. Shailasree, S., , K. K. Sampathkumara, S. R. Niranjana, \& and H. S. Prakash. 2014. Bioactive potential of medicinal plants from Western Ghats Region, India. J. Herbs Spices Med. Plants 20(3):221-234

32. Silva, N.C.C., and A. Fernandes Júnior. 2010. Biological properties of medicinal plants: a review of their antimicrobial activity. J. Venom Anim. Toxins Incl. Trop. Dis. 16(3):402-413.

33. Sule, A., Q.U. Ahmed, O.A. Samah, M.N. Omar. 2011. Bacteriostatic and bactericidal activities of Andrographis paniculata extracts on skin disease causing pathogenic bacteria. J. Med. Plant Res. 5(1):7-14.

34. Vertuani, S., E. Braccioli, V. Buzzoni, S. Manfredini. 2002. Antioxidant Capacity of Adansonia Digitata Fruit Pulp and Leaves. Acta Phytother. 5(2): 2-7.

35. Voravuthikunchai, S.P., S. Limsuwan. 2006. Medicinal plant extracts as anti-Escherichia coli $\mathrm{O} 157: \mathrm{H} 7$ agents and their effects on bacterial cell aggregation. J. Food Prot. 69(10):2336-2341.

36. Zheng, Y.T., W.L. Chan, P. Chan, H. Huang, and S.C. Tam. 2001. Enhancement of the antiherpetic effect of trichosanthin by acyclovir and interferon. FEBS Lett. 496:139-142. 